\title{
Production, composition and fatty acid profile of milk and butter texture of dairy cows fed ground or pelleted concentrate with sunflower and/or lignosulfonate ${ }^{1}$
}

\author{
Fábio José Ferreira Figueiroa ${ }^{2}$, Francilaine Eloise De Marchi ${ }^{2}$, Geraldo Tadeu dos Santos ${ }^{2}$, \\ Wallacy Barbacena Rosa dos Santos ${ }^{2}$, Daniele Cristina da Silva Kazama ${ }^{3}$, Laudí Cunha Leite ${ }^{4}$, \\ Antonio Ferriani Branco², Julio Cesar Damasceno²
}

\author{
${ }^{1}$ Project financed by Fundação Araucária and by MCT-CNPq, PRONEX, 2007. \\ ${ }^{2}$ Programa de Pós-Graduação em Zootecnia, Universidade Estadual de Maringá, Maringá, PR, Brasil. \\ ${ }^{3}$ Centro de Ciências Agrárias - Zootecnia, Universidade Federal de Santa Catarina, Florianópolis, SC, Brasil. \\ ${ }^{4}$ Centro de Ciências Agrárias, Ambientais e Biológicas, Universidade Federal do Recôncavo da Bahia, Cruz das Almas, BA, Brasil.
}

\begin{abstract}
The objective of this study was to evaluate the milk production, composition, milk fatty acid profile, butter texture and blood parameters of Holstein cows fed corn silage and concentrate containing one of the following: ground sunflower seeds; ground sunflower seeds treated with $50 \mathrm{~g}$ of lignosulfonate $/ \mathrm{kg}$ of sunflower dry matter; pelleted sunflower seeds; or ground sunflower seeds pelleted and treated with $50 \mathrm{~g}$ of lignosulfonate/kg of sunflower dry matter. Four lactating cows were used, each with $130 \pm 28$ days in lactation and a body weight of $569 \pm 63 \mathrm{~kg}$. These animals were distributed in a Latin square design with four periods of 21 days each, with 14 days of adaptation and seven days of data collection. The diets were formulated to meet nutritional requirements and had a forage:concentrate ratio of 60:40. The milk fat was lower in the pelleted treatments. The concentrations of 16:1 n-11 and trans 18:1 n-9 in the milk increased, and the n-6:n-3 ratio was higher for the pelleted treatments. The firmness and adhesiveness of the butter and the blood parameters analyzed were not affected by the treatments. Addition of lignosulfonate is not effective in protecting polyunsaturated fatty acids from the ruminal bio hydrogenation process, and the pelleting process has little effect on the milk fatty acid profile and can not change the butter texture.
\end{abstract}

Key Words: biohydrogenation, fat, firmness, metabolite, oilseed

\section{Introduction}

There is a growing demand for foods that, in addition to being nutritious, can provide other benefits to human health. Therefore, research has been conducted aiming at increasing the amount of substances beneficial to human health in foods, such as omega 3, omega 6 and conjugated linoleic acids (CLA) and, at the same time, reducing the levels of harmful substances, such as saturated fatty acids (SFA) in meat and milk, to enable ingestion of the recommended daily amounts of these nutrients (Nutrition and Health Collection, 1999; Parodi et al., 1999; Hennessey et al., 2011).

To improve the milk fatty acid profile and dairy products, the supply of fat sources rich in omega 3 and omega 6 , such as oilseeds, in the diet of dairy cows has shown to be efficient (Bett et al., 2005; Rego et al., 2005; Neves et al., 2009). The oil content in sunflower seeds varies by cultivar from 20 to $45 \%$, with a composition of $11 \%$ SFA, $27 \%$ monounsaturated (MUFA) and $60 \%$ polyunsaturated (PUFA) fatty acids, of which $60.5 \%$ is linoleic acid (Corsini et al., 2008).
In ruminants, the appearance of PUFA in milk may be compromised by the biohydrogenation process performed by rumen microorganisms as a defense against the toxicity of these fats. In an attempt to reduce the biohydrogenation process of some products, some processes, such as pelletization and addition of lignosulfonate have been adopted (Petit et al., 1999; Neves et al., 2007).

Pelleting makes food denser, reduces the selectivity and segregation of nutrients, destroys pathogens and makes the food more palatable, reducing the presence of dust particles and facilitating ingestion (Behnke, 1996; Chouinard et al., 1997). Pelletization is a type of physical processing that involves humidity and heat. According to Kennelly et al. (1996), heat treatments can reduce the extent of the ruminal biohydrogenation of PUFA. Lignosulfonate is a byproduct of wood processing and contains a variety of sugars, especially xylose, which have binding, wetting and other properties. According to Petit et al. (1999), the addition of this product to the diets of dairy cows can decrease the rumen degradability of some nutrients. 
Unsaturated fat is known to be liquid at room temperature, and the butter produced from milk enriched with this type of fat does not have the fatty acid content modified (Byers \& Schelling, 1993; Van Soest, 1994). Thus, improving the softness of butter may be possible. Therefore, the objective of this study was to evaluate the effect of pelleting and lignosulfonate addition on the production, composition and fatty acid profile of milk from cows fed diets with sunflower seeds and to determine whether the butter firmness and stickiness were affected by this type of diet.

\section{Material and Methods}

For this work, four multiparous Holstein cows averaging $569 \pm 63 \mathrm{~kg}$ of body weight (BW), $17 \pm 0.7 \mathrm{~kg}$ of milk/d and $130 \pm 28 \mathrm{~d}$ in milk were assigned to a $4 \times 4$ Latin square design to determine the effects of pelleting and lignosulfonate treatment of sunflower seeds on the DM intake, milk production, milk composition, milk fatty acid profile, butter texture and blood parameters. Each experimental period consisted of $14 \mathrm{~d}$ of adaptation to the diets and $7 \mathrm{~d}$ for data gathering.

The cows were confined in individual stalls, and feed was provided twice a day at $07 \mathrm{~h} 15$ and $16 \mathrm{~h} 00$, immediately after milking. The animals received $70 \%$ of the diet in the morning and $30 \%$ in the afternoon. The amount provided to each animal was set to have $10 \%$ remaining. The ratio of corn silage and feed concentrate was 60:40 (Table 1), which was calculated to meet the nutritional requirements of dairy cows according to the NRC (2001). The feed concentrates were offered directly in the trough and mixed with the silage.

The feed concentrates studied were as follows (Table 1): ground sunflower seeds (GS); ground sunflower seeds treated with $50 \mathrm{~g}$ of lignosulfonate $/ \mathrm{kg}$ of sunflower DM (GSL); pelleted sunflower seeds (PS); and ground sunflower seeds pelleted and treated with $50 \mathrm{~g}$ of lignosulfonate $/ \mathrm{kg}$ of sunflower DM (GSL). The lignosulfonate solution was prepared with Lignosol (Melbar, São Paulo, SP, Brazil) and contained $27 \mathrm{~g} / \mathrm{kg}$ DM of xylose. The lignosulfonate solution was added at $50 \mathrm{~g} / \mathrm{kg}$ DM after grinding the seeds but before pelleting the concentrates, as a similar concentration of lignosulfonate was shown to decrease the CP degradability and increase the milk yield (Wright et al., 2005). In the GS and PS treatments, nothing was added to substitute for the lignosulfonate.

The pelleting of the concentrates was performed with a 40 HP pelleting machine (Indústria e Comércio Chavantes Ltda, Chavantes, SP, Brazil) without steam addition at a
$75{ }^{\circ} \mathrm{C}$ exit temperature. The yield averaged $900 \mathrm{~kg} / \mathrm{h}$, and the die diameter was $4.5 \mathrm{~mm}$. New batches of concentrates were made for each of the four periods, but the same lot of ground sunflower seeds was used for the whole experiment.

Milk production was recorded at every milking. Milk samples were obtained from the four consecutive milkings on days 15 and 16 of each experimental period and pooled within the cow and period, weighted to production, to obtain one composite milk sample/cow/period for the chemical analysis. The milk samples were kept at room temperature (i.e., $23{ }^{\circ} \mathrm{C}$ ) with preservative 2-bromo-2-nitropropane-1,3 diol (Bronopol, D\&F Control Systems Inc., San Ramon, CA, USA) for determination of $\mathrm{CP}$, fat, lactose, total solids and somatic cell count concentrations. One sample from each sampling day without preservative was kept frozen to determine the milk fatty acid profile and milk urea $\mathrm{N}$ concentration. The determination of milk acidity and density was performed immediately after collection using the Dornik solution and a thermolactodensimeter, respectively.

The $\mathrm{N}$, fat, total solid and lactose concentrations in milk were determined by infrared spectroscopy (Bentley model 2000; Bentley Instrument, Inc., Chaska, MN, USA) following procedure 972.16 of the AOAC (1990). The

Table 1 - Ingredient and chemical composition of total mixed diets

\begin{tabular}{|c|c|c|c|c|}
\hline & \multicolumn{4}{|c|}{ Diets } \\
\hline & GS & GSL & PS & PSL \\
\hline \multicolumn{5}{|l|}{ Ingredient ( $\mathrm{g} / \mathrm{kg} \mathrm{DM})$} \\
\hline Corn silage & 600.0 & 600.0 & 600.0 & 600.0 \\
\hline Ground corn grain & 52.7 & 52.7 & 52.7 & 52.7 \\
\hline Soybean meal & 185.8 & 185.8 & 185.8 & 185.8 \\
\hline Mineral and vitamin supplement ${ }^{1}$ & 18.0 & 18.0 & 18.0 & 18.0 \\
\hline Limestone & 10.6 & 10.6 & 10.6 & 10.6 \\
\hline Magnesium oxide & 2.8 & 2.8 & 2.8 & 2.8 \\
\hline Salt & 6.1 & 6.1 & 6.1 & 6.1 \\
\hline Sunflower seeds & 134.0 & 134.0 & 134.0 & 134.0 \\
\hline Lignosulfonate (of sunflower DM) & - & 50 & - & 50 \\
\hline \multicolumn{5}{|l|}{ Chemical analyses } \\
\hline Dry matter ( $\mathrm{g} / \mathrm{kg}$ fresh weight) & 547.5 & 545.9 & 544.7 & 544.0 \\
\hline Organic matter $(\mathrm{g} / \mathrm{kg} \mathrm{DM})$ & 937.6 & 937.9 & 937.4 & 936.7 \\
\hline Crude protein (g/kg DM) & 181.0 & 178.4 & 177.9 & 172.7 \\
\hline Ether extract (g/kg DM) & 71.3 & 65.3 & 71.7 & 69.2 \\
\hline Neutral detergent fiber ( $\mathrm{g} / \mathrm{kg} \mathrm{DM})$ & 459.5 & 450.8 & 452.8 & 445.2 \\
\hline Acid detergent fiber (g/kg DM) & 271.5 & 268.2 & 268.8 & 265.7 \\
\hline Mineral matter (g/kg DM) & 62.4 & 62.1 & 62.6 & 63.3 \\
\hline $\mathrm{C} 16: 0$ & 8.49 & 9.65 & 8.31 & 8.46 \\
\hline $\mathrm{C} 18: 0$ & 7.11 & 6.15 & 6.08 & 5.49 \\
\hline $\mathrm{C} 18: 1 \mathrm{n} 9$ & 22.41 & 21.34 & 21.91 & 21.12 \\
\hline $\mathrm{C} 18: 2 \mathrm{n} 6$ & 60.88 & 61.38 & 62.44 & 64.40 \\
\hline $\mathrm{C} 18: 3 \mathrm{n} 3$ & 1.12 & 1.50 & 1.29 & 0.78 \\
\hline \multicolumn{5}{|c|}{ 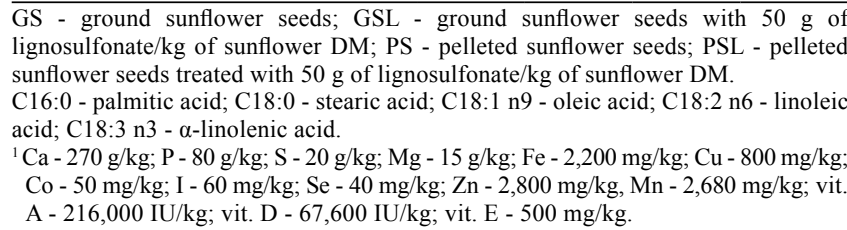 } \\
\hline
\end{tabular}


concentrations of milk urea $\mathrm{N}$ were determined according to Marsh et al. (1965). The milk somatic cell counts (SCC) were obtained using an electronic counter (Somacount $500^{\circledR}$, Chaska, MN, USA) as described by Voltolini et al. (2001).

The milk fat was separated by centrifugation as described by Murphy et al. (1995), and the milk fatty acids were methylated according to method 5509 (ISO, 1978) using $\mathrm{KOH} /$ methanol (Synth ${ }^{\circledR}$, São Paulo, Brazil) and n-heptane (Vetec ${ }^{\circledR}$, Rio de Janeiro, Brazil).

The methyl ester fatty acid profiles were measured at a split ratio of 1:100 by GLC on a Varian chromatograph (Palo Alto, CA, USA) with a G1315A auto sampler equipped with a flame ionization detector and a CP-7420 fused silica capillary column (100 m and $0.25 \mathrm{~mm}$ i.d., $0.25 \mu \mathrm{m}$ film thickness). The column parameters were as follows: the initial column temperature of $65^{\circ} \mathrm{C}$ was maintained for 4 $\mathrm{min}$; the temperature was then programmed to $20^{\circ} \mathrm{C} / \mathrm{min}$ until $170{ }^{\circ} \mathrm{C}$; the temperature of $170{ }^{\circ} \mathrm{C}$ was maintained for $20 \mathrm{~min}$ and then increased by $6{ }^{\circ} \mathrm{C} / \mathrm{min}$ to $235^{\circ} \mathrm{C}$; and the temperature of $235^{\circ} \mathrm{C}$ was maintained for $14 \mathrm{~min}$. The injector and detector temperatures were $220{ }^{\circ} \mathrm{C}$ and $240{ }^{\circ} \mathrm{C}$, respectively. The carrier gas was hydrogen at $1.2 \mathrm{~mL} / \mathrm{min}$. The hydrogen flow to the detector was $30 \mathrm{~mL} / \mathrm{min}$, the airflow was $300 \mathrm{~mL} / \mathrm{min}$, and the flow of $\mathrm{N} 2$ make-up gas was $32 \mathrm{~mL} / \mathrm{min}$. The fatty acid peaks were identified using pure methyl ester standards of the CLA isomers cis9,trans1118:2 and trans10,cis12-18:2 (cat\#05632; Sigma-Aldrich Brazil Ltd., São Paulo, SP, Brazil) and a commercial mixture of fatty acids (cat\#18919; Sigma-Aldrich Brazil Ltd.). The separations of all fatty acids were obtained in a single chromatographic run.

On the last morning of each experimental period, blood samples were collected from the animals' coccygeal vein before morning feeding. The blood samples were centrifuged at $3200 \mathrm{rpm}$ for 20 minutes, and the plasma was separated, placed in Eppendorf vials and stored at $-20{ }^{\circ} \mathrm{C}$, using methods described by Cavalieri (2003). The analyzed blood parameters were VLDL (very low density lipoprotein), LDL (low-density lipoprotein), HDL (high-density lipoprotein), total cholesterol (enzymatic photometric test), triglycerides (enzymatic colorimetric test) and glucose (enzymatic colorimetric test) on the Vitalab Selectra 2 with commercial Kits $\left(\right.$ Diasys $\left.^{\circledR}\right)$.

For butter production, 10 liters of milk were collected, proportionally to the morning and afternoon production of each animal. The collected milk was packaged in a plastic bucket and stored at $4{ }^{\circ} \mathrm{C}$ for 24 hours for cream precipitation. After 24 hours, the cream was removed and stored in plastic containers for further pasteurization at $75{ }^{\circ} \mathrm{C}$ for 30 minutes. After pasteurization, the samples were immediately cooled to $4{ }^{\circ} \mathrm{C}$ for 20 hours and beaten in a separate mixer until they turned into butter.

The butter texture analyses were made using a $45^{\circ}$ conical probe in a texture measurer TA.XT plus Texture Analyzer (Stable Micro Systems, London, UK). The probe penetrated $23 \mathrm{~mm}$ from the sample surface at a speed of $3 \mathrm{~mm} / \mathrm{s}$, where the penetration force applied on the sample was reported as the firmness of the butter, and the negative force applied to remove the probe was reported as the adhesion.

Statistical analyses were performed using the PROC MIXED procedure of SAS (Statistical Analysis System, version 9.0), with a $2 \times 2$ factorial arrangement.

The statistical model was $Y_{i j k}=\mu+T_{i}+P_{j}+A k+e_{i j k}$, where $\mathrm{Y}_{\mathrm{ijm}}=$ the observation on the repetition $\mathrm{m}$ for the treatment $i$ in the period $j ; \mu=$ the overall mean; $T_{i}=$ the treatment effect $\mathrm{i}(\mathrm{GS}, \mathrm{GSL}, \mathrm{PS}, \mathrm{PSL}) ; \mathrm{P}_{\mathrm{j}}=$ the period effect $\mathrm{j}$ $(1,2,3$ and 4); $\mathrm{Ak}=$ the animal effect (1, 2, 3 and 4); and $\mathrm{e}_{\mathrm{ij \textrm {k }}}=$ the random error associated with each observation $\mathrm{m}$, receiving treatment $\mathrm{i}$ in period $\mathrm{j}$. The treatments were compared to provide the factorial contrasts: pelleted versus non-pelleted, with lignosulfonate versus without lignosulfonate, and the interaction between pelleted and lignosulfonate. Significance was declared for $\mathrm{P}<0.05$, and tendency was accepted for $\mathrm{P}<0.10$.

\section{Results}

The milk production and fat-corrected milk yield were not affected by the diet. The content of protein, lactose, fat and total solids were not affected by the lignosulfonate (Table 2). The protein concentration, lactose, total solid, and fat yields were also not affected by the diet. However, milk from cows treated with the pelleted concentrate had a lower fat content $(\mathrm{P}=0.455)$ than milk from cows treated with the non-pelleted concentrate $(2.72 \times 3.13 \%)$.

The milk from cows fed lignosulfonate had a tendency to have increases in the concentrations of $\mathrm{C} 16: 1 \mathrm{n} 11(\mathrm{P}=0.069)$ and $\mathrm{C} 16: \ln 7(\mathrm{P}=0.053)$ in the fatty acid composition (Table 3). The concentrations of $\mathrm{C} 16: 1 \mathrm{n} 11(\mathrm{P}=0.033)$ and $\mathrm{C} 18$ : $1 \mathrm{n} 9$ trans $(\mathrm{P}=0.030)$ were higher in the milk from cows fed the pelleted diets. Moreover, a tendency was observed in the interaction effect between the lignosulfonate addition and pelleting process to decrease the $\mathrm{C} 11: 0(\mathrm{P}=0.083)$ and $\mathrm{C} 14: \ln 7(\mathrm{P}=0.803)$ fatty acids, comparing the PSL with the GS.

There were no significant effects of the experimental diets on the total saturated, monounsaturated, and polyunsaturated fatty acids or of short-, medium- and longchain fatty acids. In addition, the levels of omega 3 and 
omega 6 were not affected by the diets (Table 4$)$. However, the omega 6:omega 3 ratio was higher $(P=0.043)$ in the milk from cows fed PS and PSL compared with the nonpelleted diets $(21.2 \times 17.6)$.

In the blood parameters (Table 5), the total cholesterol and LDL levels were numerically lower in the PSL diet, but no significant difference was observed among the diets. The levels of glucose, HDL, VLDL, triglycerides and urea in the blood plasma (Table 5) were also not affected by the experimental diets.

The means of the glucose, total cholesterol, HDL, LDL, VLDL, triglycerides and urea were 64.79, 181.31, $92.5,84.89,3.93,19.63$ and $29.25 \mathrm{mg} / \mathrm{dL}$, respectively.

Finally, no effect of the diets was observed on the firmness and stickiness of the butter (Table 6). The average butter firmness and stickiness were 16.03 and $-8.236 \mathrm{~g}$, respectively.

Table 2 - Production and milk composition of Holstein cows fed the different treatments

\begin{tabular}{|c|c|c|c|c|c|c|c|c|}
\hline \multirow{2}{*}{ Variables } & \multicolumn{4}{|c|}{ Treatment } & \multirow{2}{*}{ SE } & \multicolumn{3}{|c|}{ Probability } \\
\hline & GS & GSL & PS & PSL & & $\mathrm{L}$ & $\mathrm{P}$ & I \\
\hline Dry matter intake (kg/day) & 15.50 & 16.35 & 16.25 & 15.64 & 2.04 & 0.956 & 0.992 & 0.727 \\
\hline Milk production (kg/day) & 18.18 & 17.63 & 16.85 & 16.70 & 2.80 & 0.903 & 0.696 & 0.944 \\
\hline CMY (kg/day) & 15.52 & 15.25 & 13.90 & 13.27 & 2.31 & 0.849 & 0.455 & 0.940 \\
\hline Fat (g/100 g) & 3.07 & 3.18 & 2.81 & 2.63 & 0.12 & 0.778 & 0.007 & 0.241 \\
\hline Protein $(\mathrm{g} / 100 \mathrm{~g})$ & 3.28 & 3.33 & 3.27 & 3.34 & 0.25 & 0.827 & 0.992 & 0.976 \\
\hline Lactose $(\mathrm{g} / 100 \mathrm{~g})$ & 4.36 & 4.44 & 4.32 & 4.36 & 0.16 & 0.728 & 0.716 & 0.895 \\
\hline Total solids (g/100 g) & 11.63 & 11.88 & 11.83 & 11.33 & 0.26 & 0.709 & 0.162 & 0.580 \\
\hline Fat production $(\mathrm{g} / 100 \mathrm{~g})$ & 0.55 & 0.55 & 0.48 & 0.44 & 0.08 & 0.812 & 0.312 & 0.835 \\
\hline Protein production $(\mathrm{g} / 100 \mathrm{~g})$ & 0.60 & 0.56 & 0.55 & 0.54 & 0.07 & 0.798 & 0.671 & 0.825 \\
\hline Lactose production $(\mathrm{kg})$ & 0.80 & 0.79 & 0.74 & 0.74 & 0.14 & 0.993 & 0.723 & 0.965 \\
\hline Total solids (kg) & 2.11 & 2.06 & 1.93 & 1.90 & 0.32 & 0.890 & 0.599 & 0.975 \\
\hline Somatic cell score ${ }^{1}$ & 2.70 & 2.97 & 2.82 & 2.98 & 0.22 & 0.336 & 0.762 & 0.813 \\
\hline Nitrogen urea (mg/dL) & 14.39 & 14.42 & 13.52 & 13.08 & 0.84 & 0.808 & 0.219 & 0.784 \\
\hline
\end{tabular}

GS - ground sunflower seeds; GSL - ground sunflower seeds with $50 \mathrm{~g}$ of lignosulfonate/kg DM sunflower; PS - pelleted sunflower seeds; PSL - pelleted sunflower seeds treated with $50 \mathrm{~g}$ of lignosulfonate/kg DM sunflower

SE - standard error; L - lignosulfonate effect; P - pelleted effect; I - interaction effect.

CMY $-4 \%$ fat-corrected milk yield $[0.4 \times$ milk yield $(\mathrm{kg} /$ day $)+15 \times$ fat production $(\mathrm{kg} /$ day $)],($ Gravert, 1987$)$

${ }^{1} \log 10$ somatic cell count.

Table 3 - Milk fatty acid profile (g/100 g of fatty acids) of Holstein cows fed the different treatments

\begin{tabular}{|c|c|c|c|c|c|c|c|c|}
\hline \multirow{2}{*}{ Fatty acids } & \multicolumn{4}{|c|}{ Treatment } & \multirow{2}{*}{ SE } & \multicolumn{3}{|c|}{ Probability } \\
\hline & GS & GSL & PS & PSL & & $\mathrm{L}$ & $\mathrm{P}$ & I \\
\hline $\mathrm{C} 4: 0$ & 1.08 & 0.90 & 0.90 & 0.92 & 0.17 & 0.683 & 0.617 & 0.548 \\
\hline C6:0 & 0.75 & 0.64 & 0.57 & 0.61 & 0.10 & 0.745 & 0.324 & 0.450 \\
\hline C8:0 & 0.50 & 0.42 & 0.38 & 0.40 & 0.06 & 0.608 & 0.232 & 0.333 \\
\hline C10:0 & 1.37 & 1.14 & 1.02 & 1.09 & 0.12 & 0.525 & 0.124 & 0.241 \\
\hline C11:0 & 0.11 & 0.09 & 0.07 & 0.09 & 0.01 & 0.891 & 0.083 & 0.074 \\
\hline C12:0 & 1.80 & 1.55 & 1.48 & 1.61 & 0.11 & 0.591 & 0.277 & 0.121 \\
\hline C14:0 & 8.10 & 7.44 & 7.26 & 7.74 & 0.54 & 0.882 & 0.632 & 0.322 \\
\hline $\mathrm{C} 14: \ln 11$ & 0.20 & 0.17 & 0.16 & 0.18 & 0.02 & 0.912 & 0.677 & 0.363 \\
\hline $\mathrm{C} 14: \ln 9$ & 0.52 & 0.53 & 0.48 & 0.62 & 0.05 & 0.141 & 0.598 & 0.227 \\
\hline $\mathrm{C} 14: \ln 7$ & 0.39 & 0.31 & 0.32 & 0.36 & 0.03 & 0.643 & 0.803 & 0.092 \\
\hline C15:0 & 0.62 & 0.59 & 0.60 & 0.62 & 0.05 & 0.952 & 0.874 & 0.679 \\
\hline $\mathrm{C} 15: \ln 7$ & 0.27 & 0.24 & 0.28 & 0.33 & 0.07 & 0.890 & 0.487 & 0.550 \\
\hline C16:0 & 20.21 & 21.43 & 20.46 & 21.30 & 1.06 & 0.354 & 0.955 & 0.859 \\
\hline C16:1n11 & 0.09 & 0.12 & 0.13 & 0.22 & 0.03 & 0.069 & 0.033 & 0.267 \\
\hline C16:1n9 & 0.12 & 0.14 & 0.14 & 0.21 & 0.03 & 0.135 & 0.152 & 0.360 \\
\hline $\mathrm{C} 16: 1 \mathrm{n} 7$ & 1.05 & 1.33 & 1.15 & 1.27 & 0.09 & 0.053 & 0.793 & 0.415 \\
\hline C17:0 & 0.35 & 0.31 & 0.36 & 0.38 & 0.03 & 0.684 & 0.228 & 0.300 \\
\hline $\mathrm{C} 17: \ln 7$ & 0.30 & 0.30 & 0.34 & 0.31 & 0.03 & 0.637 & 0.416 & 0.681 \\
\hline C18:0 & 18.80 & 18.60 & 18.39 & 16.03 & 0.90 & 0.189 & 0.132 & 0.259 \\
\hline $\mathrm{C} 18: \ln 9$ trans & 4.27 & 5.50 & 6.12 & 7.13 & 0.68 & 0.132 & 0.030 & 0.876 \\
\hline C18:1n9 & 33.67 & 32.74 & 33.18 & 31.76 & 1.98 & 0.566 & 0.719 & 0.906 \\
\hline $\mathrm{C} 18: 2 \mathrm{n} 6$ trans & 0.42 & 0.46 & 0.42 & 0.48 & 0.05 & 0.390 & 0.922 & 0.842 \\
\hline C18:2n6 & 3.71 & 3.74 & 4.29 & 4.40 & 0.46 & 0.873 & 0.207 & 0.938 \\
\hline C18:3n3 & 0.23 & 0.24 & 0.24 & 0.22 & 0.01 & 0.785 & 0.64 & 0.336 \\
\hline $\mathrm{C} 18: 2 \mathrm{c} 9, \operatorname{trans} 11^{1}$ & 1.09 & 1.08 & 1.32 & 1.66 & 0.37 & 0.664 & 0.304 & 0.641 \\
\hline
\end{tabular}

GS - ground sunflower seeds; GSL - ground sunflower seeds with 50 g of lignosulfonate/kg DM sunflower; PS - pelleted sunflower seeds; PSL - pelleted sunflower seeds treated with $50 \mathrm{~g}$ of lignosulfonate/ $\mathrm{kg}$ DM sunflower.

SE - standard error; L - lignosulfonate effect; P - pelleted effect; I - interaction effect.

${ }^{1}$ Conjugated linoleic acid (18:2 isomer cis-9, trans-11). 
Table 4 - Composition and ratio $(\mathrm{g} / 100 \mathrm{~g})$ of milk fatty acids of Holstein cows fed the different treatments

\begin{tabular}{|c|c|c|c|c|c|c|c|c|}
\hline \multirow{2}{*}{ Fatty acids } & \multicolumn{4}{|c|}{ Treatment } & \multirow{2}{*}{$\mathrm{SE}$} & \multicolumn{3}{|c|}{ Probability } \\
\hline & GS & GSL & PS & PSL & & $\mathrm{L}$ & $\mathrm{P}$ & I \\
\hline Saturated & 53.68 & 53.11 & 51.47 & 50.80 & 2.25 & 0.788 & 0.340 & 0.983 \\
\hline Monounsaturated & 40.87 & 41.37 & 42.28 & 42.40 & 2.02 & 0.881 & 0.559 & 0.927 \\
\hline Omega 6 & 4.13 & 4.21 & 4.71 & 4.88 & 0.47 & 0.800 & 0.218 & 0.922 \\
\hline Omega 3 & 0.23 & 0.24 & 0.24 & 0.22 & 0.01 & 0.785 & 0.624 & 0.336 \\
\hline Omega 6:omega $3^{1}$ & 17.72 & 17.47 & 20.1 & 22.34 & 1.54 & 0.535 & 0.043 & 0.440 \\
\hline Long-chain & 62.84 & 62.97 & 64.65 & 62.39 & 1.87 & 0.582 & 0.752 & 0.539 \\
\hline
\end{tabular}

GS - ground sunflower seeds; GSL - ground sunflower seeds with 50 g of lignosulfonate/kg DM sunflower; PS - pelleted sunflower seeds; PSL - pelleted sunflower seeds treated with $50 \mathrm{~g}$ of lignosulfonate/kg DM sunflower.

$\mathrm{SE}$ - standard error; L - lignosulfonate effect; P - pelleted effect; I - interaction effect

${ }^{1}$ Ratio between the total omega 6 and omega 3 fatty acids.

Table 5 - Blood parameters of Holstein cows fed the different treatments

\begin{tabular}{|c|c|c|c|c|c|c|c|c|}
\hline \multirow{2}{*}{ Metabolites (mg/dL) } & \multicolumn{4}{|c|}{ Treatment } & \multirow{2}{*}{ SE } & \multicolumn{3}{|c|}{ Probability } \\
\hline & GS & GSL & PS & PSL & & $\mathrm{L}$ & $P$ & I \\
\hline Glucose & 64.5 & 64.75 & 65.25 & 64.75 & 2.03 & 0.952 & 0.857 & 0.857 \\
\hline Total cholesterol & 182.5 & 199.75 & 185.75 & 157.25 & 24.58 & 0.824 & 0.445 & 0.376 \\
\hline High-density lipoprotein & 89.75 & 95.00 & 94.50 & 90.75 & 4.60 & 0.874 & 0.957 & 0.353 \\
\hline Low-density lipoprotein & 89.85 & 100.80 & 86.85 & 62.05 & 21.83 & 0.758 & 0.364 & 0.434 \\
\hline Very low-density lipoprotein & 2.90 & 3.95 & 4.40 & 4.45 & 1.48 & 0.718 & 0.516 & 0.743 \\
\hline Triglycerides & 14.50 & 19.75 & 22.00 & 22.25 & 7.40 & 0.718 & 0.516 & 0.743 \\
\hline Urea & 29.00 & 32.75 & 27.25 & 28.00 & 1.98 & 0.284 & 0.134 & 0.467 \\
\hline
\end{tabular}

GS - ground sunflower seeds; GSL - ground sunflower seeds with $50 \mathrm{~g}$ of lignosulfonate/kg DM sunflower; PS - pelleted sunflower seeds; PSL - pelleted sunflower seeds treated with $50 \mathrm{~g}$ of lignosulfonate $/ \mathrm{kg}$ DM sunflower.

SE - standard error; L - lignosulfonate effect; P - pelleted effect; I - interaction effect.

Table 6 - Firmness and adhesiveness of the butter from the milk of Holstein cows fed the different treatments

\begin{tabular}{|c|c|c|c|c|c|c|c|c|}
\hline \multirow{2}{*}{ Texture (g) } & \multicolumn{4}{|c|}{ Treatment } & \multirow{2}{*}{$\mathrm{SE}$} & \multicolumn{3}{|c|}{ Probability } \\
\hline & GS & GSL & PS & PSL & & $\mathrm{L}$ & $\mathrm{P}$ & I \\
\hline Firmness & 18.17 & 15.77 & 14.84 & 15.32 & 2.36 & 0.694 & 0.445 & 0.557 \\
\hline Adhesiveness & -8.474 & -8.474 & -7.970 & -8.026 & 725 & 0.970 & 0.527 & 0.970 \\
\hline
\end{tabular}

GS - ground sunflower seeds; GSL - ground sunflower seeds with 50 g of lignosulfonate/kg DM sunflower; PS - pelleted sunflower seeds; PSL - pelleted sunflower seeds treated with $50 \mathrm{~g}$ of lignosulfonate/kg DM sunflower.

SE - standard error; L - lignosulfonate effect; P - pelleted effect; I - interaction effect

\section{Discussion}

Processes such as pelleting and lignosulfonate addition in ruminant diets are performed to protect the nutrients from rumen degradation, including PUFA and protein (Petit et al., 1999; Wernersbach Filho et al., 2006). The increase in ruminal undegradable protein (RUP) is a factor that can increase milk production (Wright et al., 2005). One objective of the use of lignosulfonate and pelleting in the present study was to increase milk production through the possible protection of true protein and fat, performed by these treatments; however, this effect was not observed. Nonetheless, Santos et al. (2006) stated that gains in milk production from sources high in RUP are more likely in cows with production greater than $30 \mathrm{~kg}$ milk/day.
Similar results were also observed in other studies conducted with oilseeds and heat processing. For example, Neves et al. (2009) worked with extruded canola seeds with and without $50 \mathrm{~g} / \mathrm{kg}$ DM of lignosulfonate addition and found no significant effect on the milk production and composition. However, working with extruded soybean treated with $30 \mathrm{~g}$ of lignosulfonate $/ \mathrm{kg} \mathrm{DM}$, these same authors (Neves et al., 2007) observed a tendency to increase milk production when the animals received the extruded treatments.

The animals used in this study and those used in the studies by Neves et al. (2007) and Neves et al. (2009) were of average production: 17, 21 and $19 \mathrm{~kg}$ milk/day, respectively. Therefore, gains were more difficult to obtain. In agreement with the above findings, Wright et al. (2005), 
who worked with high-producing cows (36 kg milk/day) and evaluated the effect of diets containing untreated canola seeds, seeds treated with moist heat (extrusion) or seeds treated with wet heat and with lignosulfonate addition, observed an increase in milk production of cows fed the canola treated with heat and lignosulfonate compared with the untreated diet $(36.6 \times 34.8 \mathrm{~kg} /$ day $)$. In addition to the higher milk production of the cows used, the temperature during the extrusion process was greater than that used herein in the pelleting process.

With respect to the milk composition, similar results were also observed by Neves et al. (2007), except for the lactose level, which was increased in the milk of cows receiving treatments based on inclusion of lignosulfonate with extruded soybeans. Wright et al. (2005) also observed no differences in the milk chemical composition, except for the milk urea nitrogen (MUN) concentration, which was lower in milk from cows fed the treated canola. A reduction in the fat content in milk from the cows treated with pelleted diets was also observed by Moalem et al. (2009), who worked with thermal processing (extrusion) in the diet of dairy cows. However, the authors observed higher milk production in the cows fed extruded diets.

Fat inclusion in the diets, especially at levels above $7 \%$, can compromise the fiber degradability due to a combination of factors, including the formation of a physical barrier that coats the fiber, hindering the action of microorganisms in the rumen, and the toxicity of PUFA to the gram-positive bacteria (Palmquist, 1989; Jenkins, 1993). There are alternative methods to make the fat inert in the ruminal environment, to protect the unsaturated fatty acids and to incorporate the unsaturated fatty acids into the milk, such as the use of calcium salts and heat treatments. However, in the present work, the lignosulfonate addition and pelleting process were not efficient to accomplish these outcomes.

The reduction of fiber degradation can reduce the levels of ruminal acetic acids and, consequently, the fat content in milk. However, it was no possible to determine whether the fat content of the diet reduced the fat content in the milk because all diets had, on average, the same fat content $(7 \%)$. In the present study, the pelleting process was not efficient in protecting and improving the levels of PUFA in the milk but was efficient in reducing the fat content of milk (Tables 3 and 4). One possible explanation is that the temperature during the pelleting process may have been sufficient to rupture the fat globules, exposing the PUFA to the ruminal digestion, and yet it may have been insufficient to bind the fat with other nutrients, thus promoting the protection of the fatty acids.
This release of PUFA in the rumen may have provided an increased formation of specific isomers of C18:1 trans, which were actually higher in the pelleted diets and could be related to the milk fat decrease (Baumgard et al., 2000; Dhimam et al., 2000; Pirepova et al., 2000). According to Bauman \& Griinari (2003) and Harvatine \& Allen (2006), milk fat reduction is associated with incomplete polyunsaturated fatty acid biohydrogenation, which stimulates the duodenal flow of trans C18:1 and C18:2 10t 12c and impacts the reduction of genes related to lipogenesis.

The increase in the levels of C18:1 $\mathrm{n} 9$ trans in the milk fat of animals that were fed pellets may explain the reduction in the milk fat of these animals. Baumgard et al. (2000) concluded that the isomer C18:2 10t, 12c (CLA) is the isomer responsible for milk fat depression, but this isomer was not identified in the present study.

The results for omega 3 and omega 6 are in agreement with those of Neves et al. (2009). The increase in the omega 6:omega 3 ratio may be due to an increased ruminal release of fatty acids by the pelleting process (Mohamed et al., 1988). The omega 6:omega 3 ratio observed in the present study was high (19.4:1 on average) compared with the levels of 4 to 5:1 recommended for human consumption (Sim, 1998; Martin et al., 2006), which can be explained by the high levels of C18:2 $\mathrm{n} 6$ in sunflower seeds.

According to Tanaka (2005), the plasma level of LDL is influenced by consumed saturated fatty acids. When a diet has high saturated fat levels, the level of LDL in the bloodstream is also high, whereas a diet with higher amounts of unsaturated fats is lower in LDL. This correlation is due to the presence of polyunsaturated fatty acids that elevate the synthesis of LDL receptors in the cell, decreasing the concentration of LDL in the bloodstream (Marzzoco \& Bayardo, 1999). In the present work, the LDL levels averaged $92.5 \mathrm{mg} / \mathrm{dL}$ in the blood plasma among the treatments, and although not significant, the levels of total cholesterol and LDL were 86 and $69 \%$ lower, respectively, in the PSL treatment than in the control treatment. These results are in agreement with those of Santos et al. (2008), who added canola seeds extruded with or without lignosulfonate addition to the diet of dairy cows and did not observe significant effects of the treatment on the blood parameters evaluated.

Although no significant effects of the treatments were observed on the plasma urea levels, values slightly above those levels were observed and suggested by Fergunson et al. (1993). According to those authors, the optimal serum urea nitrogen levels should be less than $20 \mathrm{mg} / \mathrm{dL}$ to enable good reproductive performance of the herd. According 
to Johnson et al. (2002), it is common for cows fed diets containing oilseeds to have increased urea levels in the blood plasma, most likely due to the increased absorption of ruminal nitrogen.

This result helps us understand why there was no effect of the supposed increased RUP diet with the lignosulfonate use on the milk production and composition. Although not presented here, there was most likely an excess of protein in the diet or a lack of energy or synchronization between the degradation rates of carbohydrates and proteins, which may have elevated the urea nitrogen in the milk. Microbial protein production may have been lower than expected.

The lack of effect of the treatments on the firmness and stickiness of the butter can be explained by the polyunsaturated fatty acid levels and monounsaturated fat found in milk, which were similar for all treatments. The oilseed meals used in the diet of dairy cows increase the polyunsaturated fatty acid level in the milk fat (Bobe et al., 2003), and thus, according to Gonzalez et al. (2003), there may be changes in the physicochemical properties of butter.

Middaugh et al. (1988) tested the use of diets based on sunflower seeds fed to Holstein cows and found that seed addition in the diets caused an increase in the unsaturated fatty acid content in milk fat and, consequently, a higher amount of these fatty acids in the butter, making it softer compared with the control.

Bayourthe et al. (2000) evaluated the effects of supplying unsaturated fatty acids in the diet of dairy cows on the milk fatty acid prolife and the butter physical properties by providing a control diet and diets with canola seeds, crushed canola, extruded canola or canola with the addition of calcium salts. Those authors observed that the treatments containing canola showed higher amounts of unsaturated acids in the milk, resulting in improved butter spreadability.

\section{Conclusions}

Pelleted concentrates containing sunflower seeds can be used for producing milk with a lower fat content in Holstein cows. However, the pelleting process and/or lignosulfonate addition are not effective in protecting the unsaturated fatty acids of the diet or improving the milk fatty acid and butter texture.

\section{References}

ASSOCIATION OF OFFICIAL AGRICULTURAL CHEMISTS AOAC. Official methods of analysis. 14.ed. Washington, 1990.

BAUMAN, D.E.; GRIINARI, J.M. Nutritional regulation of milk fat synthesis. Annual Review of Nutrition, v.23, p.203-27, 2003.
BAUMGARD, L.H.; CORL, B.A.; DWYER, D.A. et al. Identification of the conjugated linoleic acid isomer that inhibits milk fat synthesis. American Journal of Physiology, v.278, p.R179-R184, 2000.

BYERS, F.M.; SCHELLING, G.T. Lipids in ruminant nutrition. In: CHURCH, D.C. (Ed.) The ruminant animal: digestive, physiology and nutrition. 2.ed. New Jersey: Waveland Press, 1993. p.298-312.

BAYOURTHE, C.; ENJALBERT, F.; MONCOULON, R. Effects of different forms of canola oil fatty acids plus canola meal on milk composition and physical properties of butter. Journal of Dairy Science, v.83, p.690-696, 2000.

BEHNKE, K.C. Feed manufacturing technology: current issues and challenges. Animal Feed Science Technology, v.62, p.49-57, 1996.

BETT, V.; SILVA, L.D.F. Girassol na dieta de ruminantes. In: LEITE, R.M.V.B.C.; BRIGHENTI, A.M.; CASTRO, C. (Eds.). Girassol no Brasil. Londrina: Embrapa Soja, 2005. cap.5, p.69-92.

BOBE, G; HAMMOND, E.G.; FREEMAN, A.E. et al. Texture of butter from cows with different milk fatty acid compositions. Journal of Dairy Science, v.86, p.3122-3127, 2003.

CAVALIERI, F.L.B. Lipídeos dietéticos na produção de embriões, na composição do leite e no perfil metabólicos de vacas da raça Holandesa. 2003. 101p. Tese (Doutorado em Zootecnia) Universidade Estadual de Maringá, Maringá.

CHOUINARD, P.Y.; LÉVESQUE, J.; GIRARD, V. et al. Dietary soybeans extruded at different temperatures: Milk composition and in situ fatty acid reactions. Journal of Dairy Science, v.80, p.2913-2924, 1997.

CORSINI, M.S.; JORGE, N.; MIGUEL, A.M.R.O. et al. Perfil de ácidos graxos e avaliação da alteração em óleos de fritura. Química Nova, v.31, p.956-961, 2008.

DHIMAN, T.R.; SATTER, L.D.; PARIZA, M.W. et al. Conjugated linoleic acid (CLA) content of milk from cows offered diets in linoleic acid. Journal of Dairy Science, v.83, p.1016-1027, 2000.

FERGUSON, J.D.; GALLIGAN, D.T.; BLANCHARD, T. et al. Serum urea nitrogen and conception rate: The usefulness of test information. Journal of Dairy Science, v.76, p.3742-3746, 1993.

GONZALEZ, S.; DUNCAN, S.E.; O'KEEFE, S.F. et al. Oxidation and textural characteristics of butter and ice cream with modified fatty acid profiles. Journal of Dairy Science, v.86, p.70-77, 2003.

HARVATINE, K.J.; ALLEN, M.S. Fat supplements affect fractional rates of ruminal fatty acid biohydrogenation and passage in dairy cows. Journal of Nutrition, v.136, p.677-685, 2006.

HENNESSY, A.A.; ROSS, R.P.; DEVERY, R. et al. The health promoting properties of the conjugated isomers of $\alpha$-linolenic acid. Lipids, v.46, p.105-119, 2011.

INTERNATIONAL ORGANIZATION FOR STANDARDIZATION - ISO. Animal and vegetable fats and oils - Preparation of methyl esters of fatty acids. Geneva, Switzerland, 1978 (Method ISO 5509).

JENKINS, T.C. Lipid metabolism in the rumen. Journal of Dairy Science, v.76, p.3851-3863, 1993.

JOHSON, K.A.; KINCAID, R.L.; WESTBERG, H.H. et al. The effect of oilseeds in diets of lactating cows on milk production and methane emissions. Journal of Dairy Science, v.85, p.1509-1515, 2002.

MARSH, W.H.; FINGERHUT, B.; MILLER, H. Automated and manual direct methods for the determination of blood urea. Clinical Chemistry, v.11, p.624-627, 1965.

MARTIN, C.A.; ALMEIDA, V.V.; RUIZ, M.R. et al. Ácidos graxos poli-insaturados ômega-3 e ômega-6: importância e ocorrência em alimentos. Revista de Nutrição, v.19, p.761-770, 2006.

MARZZOCO, A.; BAYARDO, B. Bioquímica básica. 2.ed. Rio de Janeiro: Guanabara Koogan, 1999. 360p.

MIDDAUGH, R.P.; BAER, R.J.; CASPER, D.P. et al. Characteristics of milk and butter from cows fed sunflower seeds. Journal of Dairy Science, v.71, p.3179- 3187, 1988.

MOALLEM, U. The effects of extruded flaxseed supplementation to high-yielding dairy cows on milk production and milk fatty 
acid composition. Animal Feed Science and Technology, v.152, p.232-242, 2009.

MOHAMED, J.J.; SATTER, L.E.; GRUMMER, R.R. et al. Influence of dietary cottonseed and soybean on milk production and composition. Journal of Dairy Science, v.71, p.2677-2688, 1988.

MURPHY, J.J.; CONNOLLY, J.F.; MCNEILL, G.P. Effects of milk fat composition and cow performance of feeding concentrates containing full fat rapeseed and maize distillers grains on grasssilage based diets. Livestock Production Science, v.44, p.1-11, 1995.

NATIONAL RESEARCH COUNCIL - NRC. Nutrient requirements of dairy cattle. 7. rev. ed. Washington, D.C.: National Academy of Sciences, 2001. 381p.

NEVES, C.A.; DOS SANTOS, W.B.R.; SANTOS, G.T. et al. Production performance and milk composition of dairy cows fed extruded canola seeds treated with or without linosulfonate. Animal Feed Science and Technology, v.154, p.83-92, 2009.

NEVES, C.A.; SANTOS, G.T.; MATSUSHITA, M. et al. Intake, digestibility, milk production, and milk composition of Holstein cows fed extruded soybeans treated with lignosulphonate. Animal Feed Science and Technology, v.134, p.32-44, 2007.

NUTRITION AND HEALTH COLLECTION. Danone Research Center. Nutritional recommendations. Lipids from alpha to omega. Paris: John Libbey Eurotext, 1999. 48p.

PALMQUIST, D.L. Lipid supplementation for lactating cows. In: SYMPOSIUM ABOUT RUMINANTS NUTRITION, 6., 1989, Piracicaba. Anais... Piracicaba: FEALQ, 1989. p.11.

PARODI, P.W. Conjugated linoleic acid and other anticarcinogenic agents of bovine milk fat. Journal of Dairy Science, v.82, p.1339-1349, 1999.

PETIT, H.V.; TREMBLEY, G.F.; TURCOTTE, M. et al. Degradability and Digestibility of full-fat soybeans treated with different sugar and heat combinations. Canadian of Journal Animal Science, v.79, p.213-220, 1999

PIREPOVA, L.S.; TETER, B.B.; BRUCKENTAL, I. et al. Mammary lipogenic enzyme activity, trans fatty acids and conjugated linoleic acids are altered in lactating dairy cows fed a milk fat-depressing diet. Journal of Nutrition, v.130, p.2568-2574, 2000.

REGO, O.A.; ROSA, H.J.D.; PORTUGAL, P.V. et al. The effects of supplementation with sunflower and soybean oils on the fatty acid profile of milk fat from grazing dairy cows. Animal Research, v.54, p.17-24, 2005.

SANTOS, F.A.P. Metabolismo proteico. In: BERCHIELLI, T.T.; PIRES, A.V.; OLIVEIRA, S.G. (Eds.) Nutrição de ruminantes. Jaboticabal: FUNEP, 2006. p.255-286.

SANTOS, G.T.; NEVES, C.A.; SILVA-KAZAMA, D.C. et al. Intake, apparent digestibility, ruminal and blood components of Holstein cows fed extruded ground canola with or without lignosulphonate. In: XXV Jubilee World Buiatrics Congress 2008, Budapeste. Hungarian Veterinary Journal, 2008. p.24-24.

SIM, J.S. Designer eggs and their nutritional and functional significance. World Review of Nutrition Dietetics, v.23, p.89-101, 1998.

TANAKA, K. Occurrence of conjugated linoleic acid in ruminant products and its physiological functions. Animal Science Journal, v.76, p.291-303, 2005.

VAN SOEST, P.J. Nutritional ecology of the ruminant. 2.ed. Ithaca, NY: Cornell University Press, 1994. 476p.

VOLTOLINI, T.V.; SANTOS, G.T.; ZAMBOM, M.A.A.S. Influência dos estádios de lactação sobre a contagem de células somáticas do leite de vacas da raça holandesa e identificação de patógenos causadores de mastite no rebanho. Acta Scientiarum, v.23, p.961-966, 2001.

WERNERSBACH FILHO, H.L.; CAMPOS, J.M.S.; ASSIS, A.J. et al. Variáveis ruminais, concentração de uréia plasmática e excreções urinárias de nitrogênio em vacas leiteiras alimentadas com concentrado processado de diferentes formas. Revista Brasileira de Zootecnia, v.35, p.1236-1241, 2006.

WRIGHT, C.F.; VON KEYSERLINGK, M.A.G.; SWIFT, M.L. et al. Heat- and lignosulphonate-treated canola meal as a source of ruminal undegradable protein for lactating dairy cows. Journal of Dairy Science, v.88, p.238-243, 2005. 